\title{
An Empirical Research of the Mechanism from Electric Vehicle Production to Charging Station R\&D in China
}

\author{
Haoxuan $\mathrm{Hu}^{1}$ and Yuchen Zhang ${ }^{2, *}$ \\ 1 College of Materials Science and Engineering, Chongqing University, Chongqing 400045, China; \\ hhx17815155067@163.com \\ 2 College of Architecture and Urban Planning, Chongqing University, Chongqing 400045, China \\ * Correspondence: lauria_zyc@163.com; Tel.: +86-13521911540
}

Citation: Hu, H.; Zhang, Y. An Empirical Research of the Mechanism from Electric Vehicle Production to Charging Station R\&D in China. Processes 2021, 9, 1407. https:// doi.org/10.3390/pr9081407

Academic Editor: Jiaqiang E

Received: 29 June 2021

Accepted: 13 August 2021

Published: 15 August 2021

Publisher's Note: MDPI stays neutral with regard to jurisdictional claims in published maps and institutional affiliations.

Copyright: (c) 2021 by the authors. Licensee MDPI, Basel, Switzerland. This article is an open access article distributed under the terms and conditions of the Creative Commons Attribution (CC BY) license (https:// creativecommons.org/licenses/by/ $4.0 /)$.

\begin{abstract}
Electric vehicles (EVs) are regarded as an effective method for dealing with serious environmental pollution. The Chinese government has implemented a series of incentives to accelerate the promotion of EV. However, the increasing production of EVs gives rise to a greater demand for better quality charging station. This study aimed to certify the impact of the production of EVs on charging station research and development (R\&D) in China, with mediating effect methods and a panel fixed effect model. The conclusions derived from the study were: (1) Statistically, the production of EVs positively and significantly impacts charging station R\&D; (2) the mediating role of investment in charging stations is verified in the relationship between the production of EVs and charging station R\&D; (3) environmental tax can moderate the relationship between the production of EVs and charging station R\&D. These results implicate, for the first time, that the production of EVs can enhance charging station R\&D through the mediating role of charging station investments and the moderating role of environmental tax.
\end{abstract}

Keywords: electric vehicles (EVs); environmental tax; charging stations; research and development

\section{Introduction}

Nowadays, the electric vehicle (EV) industry is emerging with great significance in both economic growth and environment protection [1,2]. The development of EVs correlates with the ecological goal of carbon peak and carbon neutral [3,4]. Under the policy encouragement of governments and international communities, the popularization of EVs has been increasing rapidly year by year [5-7]. The fast-growing production of EVs puts a higher demand on improving the quantity and quality of charging stations [8]. Thus, governments have started promoting the innovation and application of charging stations through more investment $[9,10]$ and incentive policies [11,12]. The optimization of charging services infrastructure will further benefit the development of the low-carbon economy $[13,14]$.

In the previous literature, the conclusions on the impact of the production of EVs on charging station R\&D in China are insufficient, and this paper attempted to investigate if the empirical evidence is substantial.

Furthermore, previous studies have shown that the production of EVs has triggered a massive growth in charging stations, which need more investment in terms of their construction $[15,16]$. Moreover, an increase in investment could promote R\&D in this industry [10]. In this case, we deduce that investments in charging stations is the mediating variable from the production of EV to charging station R\&D. However, the mediating role of investment in this relationship has not been generalized, which is one of the tasks that the present study tried to fulfill.

Some studies have shown that levying environmental tax positively affects R\&D in clean energy industries $[17,18]$. For example, Yu and Chen found that environmental tax can not only generate the market performance of EVs, but can also make a contribution to 
the development of green energy infrastructures [19,20]. Environmental tax is levied when a company releases pollutants that are harmful to the environment [21,22], and it is charged for both $\mathrm{SO}_{2}$ in air pollution and COD in water pollution [23]. Considering that the topic of this study is about EVs and charging stations, we only selected the charge rates for $\mathrm{SO}_{2}$ in air pollution (as it relates mostly to the $\mathrm{EV}$ manufacturing process) as our indicator in estimation. Authorities in mainland China have levied environmental tax to develop a green economy $[24,25]$, and these regions with higher environmental tax can incentivize vehicle manufactures to product more EVs; according to the above discussions, this will promote $R \& D$ in charging stations [26,27]. Therefore, the impact that the production of EVs has on charging station R\&D is more obvious in regions of higher rather than lower environmental tax. In this way, we suggest that environment tax can moderate the path from $E V$ production to charging station R\&D.

According to the mediating effect models, the present study analyzed whether the production of $\mathrm{EV}$ can enhance charging station $\mathrm{R} \& \mathrm{D}$ (quantified by the number of invention patents in the charging station industry in each region) through investment in charging stations. We found that the impact of production of EVs on charging station R\&D is more notable in regions of higher rather than lower environmental tax (defined by the median of tax rates), which indicates that increasing environmental tax effectively promotes the positive impact of the production of EVs on charging station R\&D.

Until now, there have been no empirical studies using investment in charging stations and environmental tax to explore the relationship between the production of EVs and charging station R\&D. In addition, the previous literature selected all kinds of patents to quantify R\&D [28,29]. Nevertheless, it is invention patents, among the three kinds of patents (invention, design, and utility model), that have the strictest requirements [30]. Therefore, one of our innovations is that we only included invention patent data rather than all patent data as a proxy of R\&D. The contributions in this study are: (1) Generalizes the direct impact path from the production of EVs to charging station R\&D for the first time; (2) conducts a deeper exploration of the mechanisms between production and R\&D, with the mediating role of investment and the moderating role of environmental tax; (3) puts forward a proposal that governments should appropriately increase environmental tax to enhance the development of the EV industry and environmental protection.

This paper is organized as follows: Section 2 discusses the role of EV production in enhancing charging station $R \& D$, and develops three hypotheses; Section 3 describes the data and uses models to analyze the empirical results; Section 4 concludes this paper.

\section{Literature Review and Hypothesis Development}

\subsection{Production of EVs and Charging Station RED}

With the accelerating progress of the ecological economy [31], clean energy is considered to be of great significance to achieve pollution reduction and energy conservation [32]. EVs are regarded as an effective method to utilize clean energy, and previous studies have shown that an increase in $\mathrm{EV}$ production can lead to pollution reduction to a great extent by replacing traditional vehicles [31,32]. For example, Teixeira found that the volume of potential harmful gas released from traditional vehicles is 10 times greater than that from EVs [33]. Elshurafa proved that carbon emissions can be reduced by $0.5 \%$ when the production of EVs is increased by 1\% [34]. Based on these facts, international organizations such as the United Nations and the WHO also appeal to the development of EVs and the surrounding industries in order to achieve better air quality [35,36].

Moreover, charging stations comprise one of the largest surrounding industries of EVs $[37,38]$. Reliable technology in charging stations is considered to be the major approach to maintaining the sustainable development of the EV industry [39-41]. As the popularization of EVs has continuously attracted increasing attention from the public, charging station R\&D has become a heated discussing issue, which is recommended by the National Development and Reform Commission in China [42,43]. 
Moreover, some studies have investigated the investment in charging stations, proving the relevance between the production of EVs and charging station development [44-46]. For example, Fang proved that an increase in the production of EVs is likely to require more charging stations, which could stimulate the investment in charging stations [44]. Nicholas and Schäuble confirmed that EV shortage is a major constraint for the investment and technical improvement of charging stations [45]. Stark also revealed that charging station services do not come meet the public's expectations, the reason of which lies in their infeasible business models and the low production of EVs [46]. Other scholars have found that sustainable prosperity of the EV market is necessary to support the development of public charging infrastructure $[47,48]$. These studies have demonstrated that the popularization of EVs has a positive impact on charging station development. However, the mechanism behind this phenomenon remains unclear.

As a result, we tried to reveal the correlation between the production of EVs and charging station $\mathrm{R} \& \mathrm{D}$, with the mediating role of charging station investment at the same time. In this study, we used the invention patent counts related to the charging stations of each provincial administrative region to measure charging station R\&D.

Accordingly, two hypotheses are proposed:

Hypothesis 1 (H1): The production of EVs is positively associated with charging station RED.

Hypothesis 2 (H2): The production of EVs correlates with charging station RED through the mediating role of charging station investment.

\subsection{Environmental Tax and Charging Station RED}

Previous studies have shown that policies about the environment, such as environmental tax, can encourage the manufacturing industry to produce more clean energy products $[18,28,49]$. The governments of all provinces in mainland China have levied different environmental tax rates to development a green economy [50-52]. The environmental tax rates vary across regions (Appendix A). Thus, the impact of the production of EVs on charging station $R \& D$ in regions with different environmental tax rates may be different.

Accordingly, we drew the conclusion that environmental tax moderates the correlation between the production of EVs and charging station R\&D, and a higher environmental tax rate strengthens the correlation between the production of EVs and charging station R\&D.

Therefore, we put forward the following hypothesis.

Hypothesis 3 (H3): Improving the environmental tax rate could strengthen the positive correlation between the production of EVS and charging station $R \mathcal{E} D$.

\section{Empirical Analysis}

This paper aimed to quantify the influence of the production of EVs on charging station R\&D in China through the mediating role of charging station investment and the moderating role of environmental tax.

\subsection{Descriptive Statistics}

The IPAT-E theory [53-55] implicates that explanatory variables such as GDP, trade openness, information infrastructure, and government size may potentially impact $R \& D$, so they were selected as control variables in this study.

We collected the panel data of 31 provinces in mainland China from 2014 to 2019, including all of our variables in this research (source: CSMAR database and Wanfang Database).

After all of the data were collected, we quantified the impact of the production of EVs on charging station R\&D through the mediator variable of charging station investment and the moderator variable of environmental tax. We used the software STATA to perform the regression in Model (1):

$$
R \& D_{i, t}=\alpha \operatorname{lnProduction}_{i, t}+\sum_{i, t} \beta_{i, t} \text { Control }_{i, t}+\varepsilon_{i, t}
$$


In the model, $\alpha$ and $\beta$ are the regression coefficients, $R \mathcal{E} D_{i, t}$ is the capacity of charging station R\&D of $i$ region in $t$ year, Production ${ }_{i, t}$ is the EV production of $i$ region in $t$ year, Control $_{i, t}$ represents all control variables of $i$ region in $t$ year, and $\varepsilon_{i, t}$ is the error term of $i$ region in $t$ year of the regression.

In Table 1, the indicators for the variables used in this study are listed. Nevertheless, there were large variations for most of our variables. For example, variables such as Production and GDP varied widely, with large SD values. To test the correlations of the variables, we report the pairwise correlations (Pearson's and Spearman's) in Table 2. None of the correlation coefficients were more than 0.35 .

Table 1. Description of statistics.

\begin{tabular}{|c|c|c|c|c|c|c|c|}
\hline & Variable & Definition & Mean & SD & Min & Median & $\operatorname{Max}$ \\
\hline $\begin{array}{l}\text { Dependent } \\
\text { variable }\end{array}$ & $\mathrm{R} \& \mathrm{D}$ & $\begin{array}{l}\text { Carbon emissions } \\
\text { (billion ton) }\end{array}$ & 0.515 & 1.101 & 0.011 & 0.351 & 1.033 \\
\hline $\begin{array}{l}\text { Independent } \\
\text { variable }\end{array}$ & Industrialization & $\begin{array}{l}\text { The proportion of the second industry in } \\
\text { GDP (\%) }\end{array}$ & 50.336 & 55.707 & 16.200 & 43.520 & 54.140 \\
\hline \multirow{4}{*}{$\begin{array}{l}\text { Control } \\
\text { variable }\end{array}$} & GDP & Gross domestic product (trillion yuan) & 40,461 & 335.807 & 920.833 & 20,363 & 107,671 \\
\hline & $\begin{array}{l}\text { Trade } \\
\text { openness }\end{array}$ & $\begin{array}{l}\text { Ratio of international trade volume to } \\
\text { GDP }(\%)\end{array}$ & 39.751 & 101.152 & 1.26 & 37.074 & 91.573 \\
\hline & $\begin{array}{l}\text { Information } \\
\text { infrastructure }\end{array}$ & $\begin{array}{c}\text { The number of internet broadband ports } \\
\text { to the local population (\%) }\end{array}$ & 36.631 & 59.750 & 19.751 & 31.201 & 55.602 \\
\hline & $\begin{array}{l}\text { Environmental } \\
\text { regulation }\end{array}$ & $\begin{array}{l}\text { Environmental protection expenditure } \\
\text { (trillion yuan) }\end{array}$ & 12.369 & 23.783 & 4.394 & 10.482 & 31.762 \\
\hline $\begin{array}{l}\text { Mediator } \\
\text { variable }\end{array}$ & Investment & $\begin{array}{l}\text { Investment in charging stations } \\
\text { (trillion yuan) }\end{array}$ & 20.472 & 41.531 & 8.147 & 16.926 & 70.361 \\
\hline $\begin{array}{l}\text { Moderator } \\
\text { variable }\end{array}$ & Environmental tax & $\begin{array}{l}\text { Environmental tax charge rates for } \mathrm{SO}_{2} \text { in } \\
\text { air pollution }\end{array}$ & 5.928 & 10.562 & 1.2 & 1.8 & 12 \\
\hline
\end{tabular}

Table 2. Pairwise correlations for all variables.

\begin{tabular}{|c|c|c|c|c|c|c|c|c|}
\hline & R\&D & Production & GDP & $\begin{array}{c}\text { Trade } \\
\text { Openness }\end{array}$ & $\begin{array}{l}\text { Information } \\
\text { Infrastructure }\end{array}$ & $\begin{array}{l}\text { Environmental } \\
\text { Regulation }\end{array}$ & Investment & $\begin{array}{c}\text { Environmental } \\
\text { Tax }\end{array}$ \\
\hline R\&D & & $0.207^{* * *}$ & $0.094^{* * *}$ & $0.347^{* *}$ & $0.006^{* * *}$ & $0.273^{* * *}$ & $0.055^{* * *}$ & $0.303 *$ \\
\hline Production & $0.291 * *$ & & $0.133^{* *}$ & $0.172 * * *$ & $0.107^{* * *}$ & $0.169 * * *$ & $0.006^{* * *}$ & $0.318 * *$ \\
\hline GDP & $0.237 * *$ & $0.097^{* * *}$ & & $0.294 * *$ & $0.014 *$ & $0.213^{* * *}$ & $0.164 * *$ & $0.099 * * *$ \\
\hline $\begin{array}{c}\text { Financial } \\
\text { development }\end{array}$ & $0.078^{* *}$ & $0.278^{* *}$ & 0.344 * & & $0.210 * *$ & $0.008^{* *}$ & $0.337^{* *}$ & $0.129^{* * *}$ \\
\hline $\begin{array}{l}\text { Information } \\
\text { infrastructure }\end{array}$ & $0.091^{* *}$ & $0.177^{* *}$ & $0.059 * *$ & $0.195 *$ & & 0.288 * & $0.008^{* * *}$ & $0.003 * *$ \\
\hline $\begin{array}{l}\text { Environmental } \\
\text { regulation }\end{array}$ & $0.331^{* * *}$ & $0.039 *$ & $0.202 *$ & $0.157^{* * *}$ & $0.260 * *$ & & 0.209 * & $0.107^{* *}$ \\
\hline Investment & $0.296 * *$ & $0.300 *$ & $0.211^{* * *}$ & $0.009 * *$ & $0.002 * * *$ & $0.346^{* *}$ & & $0.195^{* * *}$ \\
\hline Environmental tax & $0.174 * * *$ & $0.157^{* *}$ & $0.216^{* * *}$ & $0.036^{* * *}$ & $0.142 * * *$ & $0.178^{* *}$ & $0.177^{* * *}$ & \\
\hline
\end{tabular}

Note: ***, and ${ }^{* *}$ reports statistical significance at $10 \%, 5 \%$, and $1 \%$ levels.

Then, we performed Breitung panel unit root tests to test the stationarity of the data, with the following null hypothesis: A variable contains a unit root (not stationary). As is shown in Table 3, the whole panel data were highly stationary in I (0). In this way, the unit root null hypothesis was rejected.

Table 4 indicates the results of the Granger causality test. From the table, we can observe that the production of EVs is the Granger cause of charging station R\&D. However, for the test variable $R \& D$, the union significance of the coefficient has a chi-square of 0.103 and a relevant $p$-value of 0.892 , meaning that $R \& D$ is not the Granger cause of production. As a result, the evidence indicates that the production Granger causes R\&D, but the contrary does not exist, which proves H1 and is basically similar to previous studies $[18,44,46]$. 
Table 3. Unit root tests of the data.

\begin{tabular}{cc}
\hline Variable & Constant \\
\hline R\&D & $0.891^{* * *}$ \\
& 0.001 \\
\hline \multirow{2}{*}{ Production } & $1.007^{* * *}$ \\
& 0.002 \\
\hline Investment & $0.997^{* *}$ \\
Environmental tax & 0.005 \\
\hline \multirow{2}{*}{ GDP } & $1.763^{* * *}$ \\
& 0.003 \\
\hline \multirow{2}{*}{ Trade openness } & $1.243^{* * *}$ \\
& 0.002 \\
\hline \multirow{2}{*}{ Information infrastructure } & $2.033^{* *}$ \\
\hline \multirow{2}{*}{ Environmental regulation } & 0 \\
\hline \multirow{2}{*}{ ton } & $1.863^{* * *}$ \\
& 0.003 \\
\hline
\end{tabular}

Note: ${ }^{* * *} p<0.01,{ }^{* *} p<0.05 ; p$-values are reported below the coefficients.

Table 4. Causality test based on the Granger technique.

\begin{tabular}{cccc}
\hline Equation & Chi-Square & Prob. $>$ Chi-Square & Causality \\
\hline R\&D to production & 8.001 & 0.004 & Yes \\
Production to R\&D & 0.103 & 0.892 & No \\
\hline
\end{tabular}

\subsection{Baseline Results}

Due to the results of the Hausman test $(p=0.044)$, we chose fixed effects regression models to analyze the data. Table 5 reports our baseline findings and variable definitions with Robust $t$-statistics. R\&D was the dependent variable, quantified by the number of invention patents of the charging station industry, while production was the independent variable. All definitions of the variables are shown in Table 1.

Table 5. Baseline results of production and R\&D.

\begin{tabular}{ccc}
\hline R\&D & $\mathbf{1}$ & $\mathbf{2}$ \\
\hline Production & $2.077^{* * * *}$ & $1.900^{* * *}$ \\
GDP & $(3.131)$ & $(2.635)$ \\
& & $0.233^{*}$ \\
Trade openness & & $(1.868)$ \\
& & $1.239^{* * *}$ \\
Information infrastructure & & $(4.051)$ \\
Environmental Regulation & & $2.217^{* * *}$ \\
& & $(3.307)$ \\
Constant & $-51.679^{* * *}$ & $2.077^{* * *}$ \\
& $(-4.791)$ & $(3.011)$ \\
\hline Observations & 186 & $-49.071^{* *}$ \\
Adj. ${ }^{2}$ & 0.401 & $(-2.678)$ \\
\hline Note: Year and province: Fixed effect: $*<0.05^{* *} p<0.01 * * * p<0.001$ & 186 \\
& & 0.463 \\
\hline
\end{tabular}

In the first column, only the independent variable is included with the yearly and provincial fixed effects. The coefficient of the independent variable Production was 2.077 and highly significant $(p<0.001)$, revealing that production is positively correlated with 
R\&D. In the second column, controls were added to the former regression. The coefficient of Production was more significant at the $0.1 \%$ level. This implies that the correlation is still positive with controls, which shows that the results support Hypothesis 1 and affirm that the production of EVs can enhance charging station R\&D in China.

\subsection{Mediator Effect Results of Investment in Charging Stations}

Mediator analysis detects whether a variable plays a mediating role by statistical methods [56-58]. Based on former literature, mediation was tested by the causal step procedure [59-61], and all variables were analyzed in regression equations interpreted in Models (1)-(3). We infer that investment in charging stations plays a mediating role.

In the models of this research, the mediating role of investment in the process of whether production influences $R \& D$ was tested. The direct effect of production on $R \& D$ remained statistically significant, which was confirmed in the baseline results $(\alpha=2.077$, $p<0.001)$. Moreover, Investment was highly significantly and positively related to Production $\left(\alpha^{\prime}=1.734, p<0.001\right)$ in Model (2), indicating that production strengthens investment. In Model (3), the relationship between $R \mathcal{E} D$ with Production and Investment was significant $\left(\alpha^{\prime \prime}=0.924<\alpha, p<0.001\right)$. Combined with the former two models, the results indicate the statistically significant mediating effect of investment between production and R\&D. The panel fixed effect regressions of the above variables are shown in Table 6.

$$
\begin{gathered}
\text { Investment }_{i, t}=\alpha^{\prime} \text { InProduction }_{i, t}+\sum_{i, t} \beta_{i, t}^{\prime} \text { Control }_{i, t}+\varepsilon_{i, t}^{\prime} \\
R \& D_{i, t}=\alpha^{\prime \prime} \text { InProduction }_{i, t}+\sum_{i, t} \gamma_{i, t} \text { Investment }_{i, t}+\sum_{i, t} \beta^{\prime \prime}{ }_{i, t} \text { Control }_{i, t}+\varepsilon^{\prime \prime}{ }_{i, t}
\end{gathered}
$$

\begin{tabular}{|c|c|c|c|c|}
\hline \multirow{2}{*}{ Dependent Variable } & \multicolumn{2}{|c|}{ Model (2) } & \multicolumn{2}{|c|}{ Model (3) } \\
\hline & \multicolumn{2}{|c|}{ Investment } & \multicolumn{2}{|c|}{ R\&D } \\
\hline Independent Variable & Production & $\begin{array}{c}1.734^{* * *} \\
(3.429)\end{array}$ & $\begin{array}{l}\text { Production } \\
\text { Investment }\end{array}$ & $\begin{array}{c}0.924^{* * *} \\
(6.156) \\
2.451^{* * *} \\
(2.995)\end{array}$ \\
\hline \multirow{4}{*}{ Control Variable } & GDP & $\begin{array}{c}1.535^{* * *} \\
(3.975)\end{array}$ & GDP & $\begin{array}{c}1.747^{* * *} \\
(4.144)\end{array}$ \\
\hline & Trade openness & $\begin{array}{l}1.892 * * \\
(2.361)\end{array}$ & $\begin{array}{c}\text { Trade } \\
\text { openness }\end{array}$ & $\begin{array}{c}1.924^{* * *} \\
(3.521)\end{array}$ \\
\hline & $\begin{array}{l}\text { Information } \\
\text { infrastructure }\end{array}$ & $\begin{array}{l}1.246^{* * *} \\
(3.135)\end{array}$ & $\begin{array}{l}\text { Information } \\
\text { infrastructure }\end{array}$ & $\begin{array}{c}1.626^{* * *} \\
(4.145)\end{array}$ \\
\hline & $\begin{array}{l}\text { Environmental } \\
\text { regulation }\end{array}$ & $\begin{array}{c}2.274 * * * \\
(2.551)\end{array}$ & $\begin{array}{l}\text { Environmental } \\
\text { regulation }\end{array}$ & $\begin{array}{l}3.051 * * * \\
(2.797)\end{array}$ \\
\hline \multirow{2}{*}{\multicolumn{2}{|c|}{ Constant }} & $23.157^{* * *}$ & \multirow{2}{*}{ Constant } & $19.245^{* * *}$ \\
\hline & & $(3.901)$ & & $(6.125)$ \\
\hline \multirow{2}{*}{\multicolumn{2}{|c|}{$\begin{array}{l}\text { Observations } \\
\text { Adj. } R^{2}\end{array}$}} & 186 & Observations & 186 \\
\hline & & 0.301 & Adj. $\mathrm{R}^{2}$ & 0.299 \\
\hline
\end{tabular}

Table 6. Fixed effect regressions in the mediator analysis.

\subsection{Analysis of the Moderator Effect}

Appendix A shows the environmental tax charge rates for $\mathrm{SO}_{2}$ in air pollution of the different provinces in mainland China. We selected this indicator as the moderator variable. This value varies in different provinces, with a large variation.

Furthermore, all of samples of data were divided into two groups (lower tax and higher tax groups) according to different environmental tax rates. The lower tax had values less than the median (1.8 yuan/equivalent), including 14 provinces. The values of the higher tax group were greater than the median, and this group included another 17 provinces. This research performed regressions on both groups based on Model (1). In the lower tax group, only one control variable was significant, but in the higher tax group, all variables were statistically significant. 
Third, it is a feasible choice for relevant government departments in China to appropriately implement more environmental regulations and tax incentives, as it can not only stimulate the development of the EV industry, but can accelerate the process of cleaner energy applications as well.

Lastly, for other industries, regarding new energy, the government could consider providing more preferential tax policies or incentives to reward these companies with advanced technology $R \& D$ and greater innovative efforts.

Author Contributions: Software, H.H.; writing—original draft preparation, H.H.; writing—review and editing, H.H. and Y.Z.; supervision, H.H. and Y.Z.; funding acquisition, Y.Z. All authors have read and agreed to the published version of the manuscript.

Funding: The APC was funded by the Fundamental Research Funds for the Central Universities, CDXYJG0040.

Institutional Review Board Statement: Not applicable.

Informed Consent Statement: Not applicable.

Data Availability Statement: The data used in this study were acquired from https:/ /www.wanfangdata. com.cn/index.html (accessed on 20 March 2021) and https://www.gtarsc.com/ (accessed on 20 March 2021).

Conflicts of Interest: The authors declare no conflict of interests.

\section{Appendix A. Environmental Tax Charging Criterion}

Table A1. The environmental tax charge rates for $\mathrm{SO}_{2}$ in the air pollution of 31 provinces of China (yuan/per pollution equivalent).

\begin{tabular}{|c|c|c|c|c|c|}
\hline Type & Province & $\begin{array}{l}\text { Charging Criterion } \\
\text { (Yuan/Equivalent) }\end{array}$ & Type & Province & $\begin{array}{l}\text { Charging Criterion } \\
\text { (Yuan/Equivalent) }\end{array}$ \\
\hline \multirow{17}{*}{ Higher Tax Regions } & Beijing & 12 & \multirow{17}{*}{ Lower Tax Regions } & Ningxia & 1.2 \\
\hline & Tianjin & 10 & & Qinghai & 1.2 \\
\hline & Jiangsu & 8.4 & & Anhui & 1.2 \\
\hline & Shanghai & 6.65 & & Fujian & 1.2 \\
\hline & Hebei & 6 & & Tibet & 1.2 \\
\hline & Shandong & 6 & & Zhejiang & 1.2 \\
\hline & Henan & 4.8 & & Jiangxi & 1.2 \\
\hline & Sichuan & 3.9 & & Yunnan & 1.2 \\
\hline & Chongqing & 3.5 & & Inner Mongolia & 1.2 \\
\hline & Hainan & 2.4 & & Xinjiang & 1.2 \\
\hline & Guizhou & 2.4 & & Liaoning & 1.2 \\
\hline & Hunan & 2.4 & & Gansu & 1.2 \\
\hline & Hubei & 2.4 & & Shaanxi & 1.2 \\
\hline & Shanxi & 1.8 & & Jilin & 1.2 \\
\hline & Guangdong & 1.8 & & & \\
\hline & Guangxi & 1.8 & & & \\
\hline & Heilongjiang & 1.8 & & & \\
\hline
\end{tabular}

\section{References}

1. Elizabeth, A.M.; Jennifer, D.R.; Callie, W.B.; Brian, T.; Susan, S.C. Spatial modeling of a second-use strategy for electric vehicle batteries to improve disaster resilience and circular economy. Resour. Conserv. Recycl. 2020, 160, 104889.

2. Simone, F.; Alessio, N. The environmental impact of electric vehicles: A novel life cycle-based evaluation framework and its applications to multi-country scenarios. J. Clean. Prod. 2021, 315, 128005.

3. Liu, L.; Xie, F.; Huang, Z.; Wang, M. Multi-Objective Coordinated Optimal Allocation of DG and EVCSs Based on the V2G Mode. Processes 2021, 9, 18. [CrossRef]

4. Zou, C.N.; Xiong, B.; Xue, H.Q.; Zheng, D.V. The role of new energy in carbon neutral. Pet. Explor. Dev. 2021, 48, 480-491. [CrossRef]

5. Kong, D.Y.; Xia, Q.H.; Xue, Y.X.; Zhao, X. Effects of multi policies on electric vehicle diffusion under subsidy policy abolishment in China: A multi-actor perspective. Appl. Energy 2020, 266, 114887. [CrossRef]

6. Tang, Q.; Shu, X.; Zhu, G.; Wang, J.; Yang, H. Reliability Study of BEV Powertrain System and Its Components-A Case Study. Processes 2021, 9, 762. [CrossRef] 
7. Li, W.; Long, R.; Chen, H.; Dou, B.; Chen, F.; Zheng, X.; He, Z. Public Preference for Electric Vehicle Incentive Policies in China: A Conjoint Analysis. Int. J. Environ. Res. Public Health 2020, 17, 318. [CrossRef]

8. Nilgun, F.U.; Fescioglu, U.; Melike, Y.A.; Coşku, K. Feedback controlled resource management model for express service in electric vehicle charging stations. J. Clean. Prod. 2021, 311, 127629.

9. Liu, X.; Ma, J.; Zhao, X.; Zhang, Y.; Zhang, K.; He, Y. Integrated Component Optimization and Energy Management for Plug-In Hybrid Electric Buses. Processes 2019, 7, 477. [CrossRef]

10. Reza, S.; Meysam, J.N.; Javad, S. Allocation of RESs and PEV Fast-Charging Station on Coupled Transportation and Distribution Networks. Sustain. Cities Soc. 2021, 65, 102527.

11. Atawi, I.E.; Hendawi, E.; Zaid, S.A. Analysis and Design of a Standalone Electric Vehicle Charging Station Supplied by Photovoltaic Energy. Processes 2021, 9, 1246. [CrossRef]

12. Zhang, J.; Wang, Z.; Zhao, H. The Impact of Consumer Subsidy on Green Technology Innovations for Vehicles and Environmental Impact. Int. J. Environ. Res. Public Health 2020, 17, 7518. [CrossRef]

13. Valenti, G.; Murgia, S.; Costanzo, I.; Scarnera, M.; Battistella, F. Experimental Determination of the Performances during the Cold Start-Up of an Air Compressor Unit for Electric and Electrified Heavy-Duty Vehicles. Energies 2021, 14, 3664. [CrossRef]

14. Richard, W.; Hsu, S.C.; Zheng, S.; Chen, J.H.; Li, X.I. Renewable energy microgrids: Economic evaluation and decision making for government policies to contribute to affordable and clean energy. Appl. Energy 2020, 274, 115287.

15. Fang, Y.J.; Wei, W.; Mei, S.W.; Chen, L.J. Promoting electric vehicle charging infrastructure considering policy incentives and user preferences: An evolutionary game model in a small-world network. J. Clean. Prod. 2020, 258, 120753. [CrossRef]

16. Ma, T.Y.; Xie, S.M. Optimal fast charging station locations for electric ridesharing with vehicle-charging station assignment. Transp. Res. Part D Transp. Environ. 2021, 90, 102682. [CrossRef]

17. Zhou, Z.; Yu, H.L.; Shao, Q. Tax and subsidy policy for domestic air pollution with asymmetric local and global spillover effects. J. Clean Prod. 2021, 318, 128504. [CrossRef]

18. Song, M.L.; Wang, S.H.; Zhang, H.Y. Could environmental regulation and R\&D tax incentives affect green product innovation? J. Clean Prod. 2020, 258, 120849.

19. Zhu, X.X.; Raymond, C.; Liu, K. Dilemma of introducing a green product: Impacts of cost learning and environmental regulation. Appl. Math. Model. 2021, 92, 829-847. [CrossRef]

20. Shamal, C.K.; Shahadat, H. The role of environmental taxes on technological innovation. Energy 2021, $232,121052$.

21. President of the People's Republic of China. Environmental Tax Law of the People's Republic of China. In Proceedings of the 25th Meeting of the Standing Committee of the Twelfth National People's Congress, Beijing, China, 25 December 2016.

22. Thomas, I.R.; Luca, S.; Laura, M. Can subsidies rather than pollution taxes break the trade-off between economic output and environmental protection? Energy Econ. 2021, 95, 105084.

23. Yu, X.M.; Geng, Y.; Dong, H.J.; Tsuyoshi, F. Emergy-based sustainability assessment on natural resource utilization in 30 Chinese provinces. J. Clean. Prod. 2016, 133, 18-27. [CrossRef]

24. Chen, S. Marginal emission reduction cost and China's environmental tax reform. Soc. Sci. 2011, 3, 222.

25. Ernani, F.; John, S.E.; James, K.H. Assessing the health impacts of electric vehicles through air pollution in the United States. Environ. Int. 2020, 144, 106015.

26. Ankit, Y.; Anbesh, J.; Rajeev, A. Environmental impacts assessment during sand casting of Aluminium LM04 product: A case of Indian manufacturing industry. Procedia CIRP 2021, 98, 181-186.

27. Lee, S.H.; Chul, H.P. Environmental regulations in private and mixed duopolies: Taxes on emissions versus green R\&D subsidies. Econ. Syst. 2021, 45, 100852.

28. Adnan, S.; Chen, Y.Y.; Salman, W.; Liya, Z. Does environmental taxes achieve the carbon neutrality target of G7 economies? Evaluating the importance of environmental R\&D. J. Environ. Manag. 2021, 293, 112908.

29. Lin, N.H.; Muhammad, U.; Zeeshan, K. Green growth and low carbon emission in G7 countries: How critical the network of environmental taxes, renewable energy and human capital is? Sci. Total Environ. 2021, 752, 141853.

30. Kenneth, G.L.; Can, H.; Shen, H.J. Assessing the value of China's patented inventions. Technol. Forecast. Soc. Chang. 2021, $170,120868$.

31. Annibal, S.; Gláucya, D.; Daú, L.F.S. Social and ecological approaches in urban interfaces: A sharing economy management framework. Sci. Total Environ. 2020, 713, 134407.

32. Muhammad, U.; Muhammad, S.A.; Sohail, A.M. Does financial growth? Fresh evidence from 15 highest emitting countries. Sustain. Cities Soc. 2021, 65, 102590.

33. Teixeira, A.C.R.; Sodre, J.R. Simulation of the impacts on carbon dioxide emissions from replacement of a conventional Brazilian taxi fleet by electric vehicles. Energy 2016, 115, 1617-1622. [CrossRef]

34. Elshurafa, A.M.; Peerbocus, N. Electric vehicle deployment and carbon emissions in Saudi Arabia: A power system perspective. Electr. J. 2020, 33, 106774. [CrossRef]

35. Sustainable Development Goals: Goal 7: Affordable and Clean Energy. United Nations Sustainable Development Goals. Available online: https://unstats.un.org/sdgs/report/2016/goal-07/ (accessed on 1 April 2021).

36. World Environmental Day: Ensure Rapid and Healthy Energy Conversion. W.H.O. 73rd World Health Assembly. Available online: https:/ / www.who.int/news-room/ feature-stories/detail/73rd-world-health-assembly-decisions (accessed on 7 August 2020). 
37. Yang, M.; Zhang, L.H.; Wang, L.W. Comprehensive benefits analysis of electric vehicle charging station integrated photovoltaic and energy storage. J. Clean. Prod. 2021, 302, 126967. [CrossRef]

38. Li, C.Z.; Zhang, L.B. Robust model of electric vehicle charging station location considering renewable energy and storage equipment. Energy 2021, 238, 121713. [CrossRef]

39. Olusola, B.; Sandra, O.; Huang, Q.; Nasser, Y.M. Impact of economic development on $\mathrm{CO}_{2}$ emission in Africa; the role of BEVs and hydrogen production in renewable energy integration. Int. J. Hydrogen Energy 2021, 46, 2755-2773.

40. Zhai, H.; Frey, H.C.; Rouphail, N.M. Development of a modal emissions model for a hybrid electric vehicle. Transp. Res. Part D Transp. Environ. 2011, 16, 444-450. [CrossRef]

41. Sevgi, E.; İsmail, Ç.; İbrahim, Ç. Establishing a statewide electric vehicle charging station network in Maryland: A corridor-based station location problem. Socio-Econ. Plan. Sci. 2021, 101127. [CrossRef]

42. Balasundar, C.; Sundarabalan, C.K.; Sharma, J.; Srinath, N.S.; Guerrero, J.M. Design of Power Quality Enhanced Sustainable Bidirectional Electric Vehicle Charging Station in Distribution Grid. Sustain. Cities Soc. 2021, 74, 103242. [CrossRef]

43. National Development and Reform Commission. National Development and Reform Commission and Other Departments Answered Reporters' Questions on 'The Implementation Plan of Accelerating the Cultivation of New Consumption'. Beijing, China. Available online: https:/ / www.ndrc.gov.cn/xxgk/jd/jd/202104/t20210401_1271576.html?code=\&state=123 (accessed on 1 April 2021).

44. Nicholas, M.; Tal, G. Transitioning to longer range battery electric vehicles: Implications for the market, travel and charging. $S A E$ Int. 2017, 115, 1617-1622.

45. Schäuble, J.; Kaschub, T.; Ensslen, A.; Jochem, P. Generating electric vehicle load profiles from empirical data of three EV fleets in Southwest Germany. J. Clean. Prod. 2017, 150, 253-266. [CrossRef]

46. Stark, J.; Weiß, C.; Trigui, R.; Franke, T.; Baumann, M.; Jochem, P. Electric vehicles with range extenders: Evaluating the contribution to the sustainable development of metropolitan regions. J. Urban Plan. Dev. 2018, 144, 04017023. [CrossRef]

47. Neaimeh, M.; Salisbury, S.D.; Hill, G.A.; Blythe, P.T.; Sco, D.R.; Francfort, J.E. Analysing the usage and evidencing the importance of fast chargers for the adoption of battery electric vehicles. Energy Policy 2017, 108, 474-486. [CrossRef]

48. Axsen, J.; Langman, B.; Goldberg, S. Confusion of innovations: Mainstream consumer perceptions and misperceptions of electric-drive vehicles and charging programs in Canada. Energy Res. Soc. Sci. 2017, 27, 163-173. [CrossRef]

49. Bashir, M.F.; Benjiang, M.A.; Shahbaz, M.; Shahzad, U.; Vo, X.V. Unveiling the heterogeneous impacts of environmental taxes on energy consumption and energy intensity: Empirical evidence from OECD countries. Energy 2021, 226, 120366. [CrossRef]

50. Wang, Y.; Yu, L.H. Can the current environmental tax rate promote green technology innovation?-Evidence from China's resource-based industries. J. Clean. Prod. 2021, 278, 123443. [CrossRef]

51. Zhang, S.H.; Mendelsohn, R.; Wang, C. Evaluating environmental tax rates for power plants in BTH area based on marginal damage estimation: An Integrated Assessment. Energy Procedia 2019, 158, 3923-3929. [CrossRef]

52. Li, P.N.; Lin, Z.G.; Du, H.B.; Feng, T.; Zuo, J. Do environmental taxes reduce air pollution? Evidence from fossil-fuel power plants in China. J. Environ. Manag. 2021, 295, 113112. [CrossRef]

53. Peng, L.; Dong, D.X.; Wang, Z. The impact of air pollution on R\&D input and output in China. Sci. Total Environ. 2021, 752, 141313.

54. Magee, C.L.; Devezas, T.C. Specifying technology and rebound in the IPAT identity. Procedia Manuf. 2018, 21, 476-485. [CrossRef]

55. Janis, B.; Kuishuang, F.; Klaus, H. Drivers of CO2 emissions in the former Soviet Union: A country level IPAT analysis from 1990 to 2010. Energy 2013, 59, 743-753.

56. Fanny, M.; Pierre, V.F.; Virginie, D.B. Modeling the effects of place heritage and place experience on residents' behavioral intentions toward a city: A mediation analysis. J. Bus. Res. 2021, 134, 428-442.

57. Cashin, A.G.; Lee, H. An introduction to mediation analyses of randomized controlled trials. J. Clin. Epidemiol. 2021, 133, 161-164. [CrossRef]

58. Zeng, P.; Shao, Z.H.; Zhou, X. Statistical methods for mediation analysis in the era of high-throughput genomics: Current successes and future challenges. Comput. Struct. Biotechnol. J. 2021, 19, 3209-3224. [CrossRef] [PubMed]

59. Hayes, A.F.; Beyond, B. Statistical Mediation Analysis in the New Millennium. Commun. Monogr. 2009, 76, 408-420. [CrossRef]

60. Christine, E.P.; Robert, Z.; Christoffer, L.; Katherine, S.Y. How does cognitive behavioural therapy for insomnia work? A systematic review and meta-analysis of mediators of change. Clin. Psychol. Rev. 2021, 86, 102027.

61. Steven, H.J.; Dawn, K.; Elizabeth, H.; Fiona, L. Mediation analysis of recovery-focused therapy for recent-onset bipolar disorder. J. Affect. Disord. Rep. 2021, 5, 10017. 